\title{
Analysis Of The Dynamics Of Cashless Payments In Kazakhstan In The Context Of The Covid-19 Pandemic
}

\author{
A. Kredina ${ }^{1}$, A. Akparova ${ }^{2}$, L. Vasa $^{3}$ \\ ${ }^{1}$ University of International Business, ${ }^{2}$ Kazakhstan University of International Relations and \\ World Languages named Abylai Khan, ${ }^{3}$ Széchenyi István University
}

\begin{abstract}
Annotation
The COVID-19 pandemic has accelerated the development of FinTech and the transition to cashless payments of the population of various countries, including Kazakhstan. For provision of cashless payments there are created platforms which work in NFC \& MFS systems, they protected by security protocols (Secure Element (SE)) and allow to store confidential user data. Changes in the business model of banks have led to the emergence of a new format of banking products and services that can be used through smartphones (the main operating systems Android and iOS). The goal of the study is to analyze the dynamics of the impact of the COVID-19 pandemic on the use of cashless payments through national payment systems in Kazakhstan. Based on the goal, a null and an alternative hypothesis were set, of which the second was confirmed in the result. Research methods used to write this article are economic and statistical analysis and synthesis, graphical method, analysis of the series of dynamics. The data for the study was taken from the NBK Statistical Bulletin: data on cashless payments through the Interbank System of Money Transfer (ISMT) and the Interbank Clearing System (ICS) for the period from 2002 to 2020. The impact of the COVID-19 pandemic on the dynamics of the transformation of cashless payments made by using financial technologies has been proved. Recommendations for further improvement of the financial system are given. The development of national payment systems makes it possible to reduce the level of fraud in the financial sector, to increase the speed of cashless transfers and level out transaction errors. Study limitation: only national payment systems ISMT and ICS were used.

Keywords: FinTech, COVID-19, cashless payments, financial platforms, transformation
\end{abstract}

\section{Covid-19 пандемиясы жағдайында Қазақстандағы қолма-қол ақшасыз төлемдер динамикасын талдау}

\section{Түйін}

COVID-19 пандемиясы FinTech-тің дамуын және әр түрлі елдердің, оның ішінде Қазақстанның тұрғындарының қолма-қол ақшасыз төлемдеріне көшуді жеделдетті. Қолма-қол ақшасыз төлемдер үшін NFC \& MFS жүйелерінде жұмыс істейтін платформалар құрылады, олар қауіпсіздік протоколдарымен қорғалған (Secure Element (SE)), бұл пайдаланушының құпия деректерін сақтауға мүмкіндік береді. Банктердің бизнесмоделіндегі өзгерістер смартфондармен (банктік Android және iOS операциялық жүйелерімен) пайдалануға болатын банктік өнімдер мен қызметтердің жаңа форматының пайда болуына әкелді Зерттеудің мақсаты банктердің әсер динамикасын талдау COVID-19 пандемиясы Қазақстандағы ұлттық төлем жүйелері арқылы қолма-қол жасалмайтын төлемдерді қолдану. Мақсат негізінде нөлдік және альтернативті гипотеза қойылды, оның нәтижесінде екіншісі расталды. Осы мақаланы жазу үшін қолданылған зерттеу әдістері: экономикалық және статистикалық талдау және синтез, графикалық әдіс, динамиканың серияларын талдау. Зерттеуге арналған деректер ҚҰБ-нің статистикалық бюллетенінен алынды: ақша аударымдарының банкаралық жүйесі (БААЖ) және банкаралық клиринг жүйесі (ICS) арқылы қолма-қол ақшасыз төлемдер туралы мәліметтер 2002 жылдан бастап 2020 жылға дейінгі аралықта. COVID-19 пандемиясының қаржылық технологияларды қолдана отырып жасалған қолма-қол ақшасыз төлемдердің өзгеру динамикасына әсері дәлелденді. Қаржы жүйесін одан әрі жетілдіру бойынша ұсыныстар берілді. Ұлттық төлем жүйелерінің дамуы қаржы саласындағы алаяқтық деңгейін төмендетуге, қолма-қол ақшасыз аударымдардың жылдамдығын арттыруға және транзакциялық қателіктерді түзетуге мүмкіндік береді. Зерттеуді шектеу: тек ISMT және ICS ұлттық төлем жүйелері пайдаланылды.

Tүüін сөздер: FinTech, COVID-19, қолма-қолсыз төлемдер, қаржы платформалары, трансформация

\section{Анализ динамики безналичных платежей в Казахстане в условиях пандемии COVID-19}

\section{Аннотация}

Пандемия COVID-19 ускорила развитие FinTech и переход к безналичным платежам населения различных стран, в том числе и Казахстана. Для проведения безналичных платежей создаются платформы, работающие в системах NFC \& MFS, которые защищены протоколами безопасности (Secure Element (SE)), что позволяет хранить конфиденциальные данные пользователей. Изменение бизнес-моделей банков привело к появлению нового формата банковских продуктов и услуг, которыми можно пользоваться при помощи смартфонов (основные оперативные системы Android и iOS). Цель исследования - проанализировать динамику влияния пандемии COVID-19 на использование безналичных платежей через национальные платежные системы в Казахстане. Исходя из цели были поставлены нулевая и альтернативная гипотезы, из которых вторая в результате подтвердилась. Методы исследования, применяемые для написания данной статьи: экономико-статистический анализ и синтез, графический метод, анализ рядов динамики. Данные для исследования были взяты из Статистического бюллетеня НБК: данные по безналичным платежам, 
проходящим через Interbank System of Money Transfer (ISMT) и Interbank Clearing System (ICS) за период c 2002 по 2020 годы. Доказано влияние пандемии COVID-19 на динамику трансформации безналичных платежей, осуществляемых при использовании финансовых технологий. Даны рекомендации для дальнейшего совершенствования финансовой системы. Развитие национальных платежных систем позволяет снизить уровень мошенничества в финансовой сфере, повысить скорость безналичных переводов и нивелировать транзакционные ошибки. Ограничение в исследовании: использованы только национальные платежные системы ISMT and ICS.

Ключевые слова: FinTech, COVID-19, безналичные платежи, финансовые платформы, трансформация

\section{Introduction}

The financial crisis of 2008 - it was then that a new direction related to the development of financial technologies began to develop actively; FinTech. Financial technologies are constantly transforming. Advances in computing, mathematics, statistics, psychology, econometrics, linguistics, cryptography, big data, and computer interfaces have combined and fintech is now being used in many areas [1]. At the same time, there are being created such platforms which can be integrated between economic sectors, contributing to the economic growth of some countries, technically uniting states.

There was conducted a study of the number of downloads of mobile applications in 74 countries through the Play Market platform (for Android and iOS systems). As a result of the study, it was revealed that users of the Android system (the population of developing countries, including China, Kazakhstan, etc.) have been actively downloading mobile applications for cashless payments for smartphones since mid-February. This was the beginning of a "hard lockdown" all over the world. Interestingly, at the same time, users of the iOS system (the population of developed countries) began to download such applications even in smaller numbers [2]. Clearly, the COVID-19 pandemic has accelerated the transformation of financial technology.

The purpose of the study is to collect and process statistical data, analyze the dynamics of the impact of the COVID-19 pandemic on the use of cashless payments through national payment systems in Kazakhstan. Based on the goal, the following hypotheses can be put (zero and alternative):

H0 - hypothesis 0 - the COVID-19 pandemic did not affect the use of cashless payments in Kazakhstan.

H1 - hypothesis 1 - the COVID-19 pandemic has impacted the use of cashless payments in Kazakhstan.

\section{Literature review}

During the COVID-19 pandemic, the use of mobile payments increased globally, as the population feared using contact payment methods due to the possibility of infection [3]. Scientists in their research give the following definition of mobile payment (M-payment) - “... transferring money to services or goods over mobile devices via Short Message Service (SMS), Browser, payment applications, and Quick Response (QR) code" [4]. The reasons of cashless payments spread is the coverage of the Internet by a large number of population [5].

In the context of the COVID-19 pandemic, the most pressing issue is the implementation of the State Program "Digital Kazakhstan" (there are 23 main projects in the field of information and communication technologies (ICT). The fifth objective in the program is the development of financial technologies and cashless payments in Kazakhstan. One of the subpoints is the development of financial literacy among the population, which is the key factor that will contribute to the spread of financial technology [6]. According to research by scientists, financial literacy among young people contributes to the development of entrepreneurship among young population and contributes to the accumulation of capital at retirement $[7,8]$.

There are two types of platforms for cashless payments in Kazakhstan: banking and non-banking. Banking platforms are included in the "Register of payment systems operating in Kazakhstan", their development is actively supported by the state. Some authors wrote that for the development and success of a new financial business model, it is necessary to adhere to the principles of LASIC, namely: government support and coverage of that part of the market where there is low competition [9]. For example, following these principles, Kaspi Bank, with its mobile transfer application, gained popularity among more than 7 million users and went public in 2020. Among the population, the words "Kaspi Gold" are even used, meaning the transfer of cashless money.

In his study, Chen L. also believes that in addition to technology, an important element is the ability of technology to meet market needs [10]. Like Chinese companies, Kaspi's innovative app hit the market at the right time and offered the population the convenience of cashless payments. Development of Kaspi Kartomat, which is the only terminal in the world that issues personalized 
cards, Kaspi POS-terminal for accepting payments without a payment card via QR, application of Kaspi ID and Kaspi e-Sign technologies for opening and closing loans and deposits online. And finally, the creation of an electronic trading platform. All this has contributed to the distribution of the Kaspi.kz application on the territory of Kazakhstan.

The most important thing for any payment system is security. In 2008, the NFC system was adopted, over time, alternatives appeared: Secure Micro SD card, UICC, eSE, TMB, based on NFC technologies and tied to mobile phones [11]. Then came the MFS ecosystem, which has gained popularity lately. This is due to the new security protocols (SE). There is an opinion among scholars that this particular system will eventually occupy a large part of the cashless payment market. It is the MFS system that makes it possible to perform not only transfer transactions, but also the ability to provide other banking services remotely: loans, deposits, insurance, etc. [12,13].

This system is also used by electronic wallets, which, as a separate branch of fintech, managed to enter not only the banking system. Payment systems (Visa, PayPal etc.), manufacturers (SamsungPay, AliPay) technology giants (Google, Yandex, etc.), mobile operators (Activ, Bilene etc.) and many others create their own e-wallets and are subject to the new business model, which is built between banks and customers [14]. But simply implementing an electronic wallet is not enough, big data proper management is needed, since the trend of recent years is the platformization of technologies and, accordingly, data accumulation [15].

In the banking system, the largest data is accumulated in national payment systems, since the interbank clearing system is applied in all banks operating in the country. The organization of national payment systems aims to reduce fraud in the financial sector, speed up wire transfers and reduce transaction errors [16].

\section{Metodology}

The COVID-19 pandemic is impacting emerging market economies through an unprecedented combination of internal and external shocks.

The theoretical and methodological basis of the study was the works of foreign and domestic scientists. Research methods used to write this article: economic-statistical analysis and synthesis, graphical method, analysis of series of dynamics [17]. Previously, it has been proved that research is more profitable in terms of financial and time aspects using electronic platforms [18]. Therefore, informational data for the article was taken from the website of the National Bank of the Republic of Kazakhstan.

The Statistical Bulletin of the NBK was studied: data on cashless payments passing through the Interbank System of Money Transfer (ISMT) and the Interbank Clearing System (ICS) for the period from 2002 to 2020 ("Statistical Bulletin...", 2002-2020) [19]. The information was processed using Microsoft Excel programs, the analytical service "Indicators of a number of dynamics online" was used.

Dynamics indicators are calculated on a constant and variable basis. If to compare each level of the series with the original year (for example, 2002 is taken as a basis), then basic calculations of the indicators of dynamics can be can be made. To do this, each subsequent year is compared with the base year. If, however, to compare each subsequent year with the previous one, then chain dynamics indicators are obtained. Table 1 shows the basic formulas used for the calculations.

\section{Table 1 - Formulas for calculating indicators of a number of dynamics}

\begin{tabular}{|c|c|c|}
\hline Index & The formula for the chain indicators & The formula for the basic key figures \\
\hline Absolute increase & $\Delta$ уц $=$ yi - yi-1 & $\Delta y б=$ уі - убаз \\
\hline Coefficient rate & Ky = yi / yi-1 & Ку баз = убі / убаз \\
\hline Rate of rate & Ty $\mathrm{i}=$ yi / yi-1 & Ту баз = убі / y1 \\
\hline Coefficient increase & Кпр $=$ Кр -1 & Кпр баз = Кр баз - 1 \\
\hline Rate of increase & $\begin{array}{l}\text { Тпрці = } \Delta \text { уi } / \text { yi-1 * 100, } \\
\text { Тпр = Тр }-100 \%\end{array}$ & Тпрб = Аубі / у1 \\
\hline Absolute value of $1 \%$ increase & $\begin{array}{l}\mathrm{A}=\Delta у ц \text { / Тпр ц, } \\
\text { 1\%ці = yi-1 / 100\% }\end{array}$ & $\begin{array}{l}A=\text { =убаз / Тпр баз, } \\
1 \% \text { = уб / } 100 \%\end{array}$ \\
\hline Rate of build-up & Тн = Ауці / у1 & Тн = Ауці / у1 \\
\hline
\end{tabular}


Absolute gain - as the difference between this level and the level taken as the comparison base.

Growth rate - is defined as the ratio of the absolute growth of a given level to the previous or baseline.

Growth rate is the ratio of two levels of a series and can be expressed as a coefficient or as a percentage.

The absolute value of $1 \%$ growth is the ratio of the absolute growth to the growth rate, expressed in $\%$, shows the significance of each percentage of the growth over the same period of time [21].
Growth rate - measures the build-up of economic potential over time.

\section{Results and discussion}

Through the national payment systems as Interbank System of Money Transfer (ISMT) and Interbank Clearing System (ICS), for 18 years of existence, more than 500 thousand transactions (more than 5,468 trillion tenge) have been carried out. Table 2 shows the results of chain indicators of a number of dynamics.

Table 2 - Chain indicators of a number of dynamics of ISMT and ICS

\begin{tabular}{|c|c|c|c|c|c|c|c|c|c|c|c|c|}
\hline \multirow[b]{2}{*}{$\cdot \frac{\overline{0}}{0}$} & \multirow{2}{*}{$\begin{array}{l}\text { ISMT } \\
\text { and } \\
\text { ICS, } \\
\text { volume } \\
\text { (bln. } \\
\text { KZT) }\end{array}$} & \multirow[b]{2}{*}{$\begin{array}{l}\text { ISMT and } \\
\text { ICS, value } \\
\text { (thous. } \\
\text { transac- } \\
\text { tions) }\end{array}$} & \multicolumn{2}{|c|}{$\begin{array}{l}\text { Absolute in- } \\
\text { crease }\end{array}$} & \multicolumn{2}{|c|}{ Growth rate, $\%$} & \multicolumn{2}{|c|}{$\begin{array}{c}\text { Rates of growth, } \\
\% \\
\end{array}$} & \multicolumn{2}{|c|}{$\begin{array}{l}\text { Absolute content } \\
\text { of } 1 \% \text { growth }\end{array}$} & \multicolumn{2}{|c|}{$\begin{array}{l}\text { The rate of in- } \\
\text { crease, } \%\end{array}$} \\
\hline & & & $\begin{array}{c}\text { ISMT } \\
\text { and ICS, } \\
\text { volume }\end{array}$ & $\begin{array}{l}\text { ISMT } \\
\text { and } \\
\text { ICS, } \\
\text { value }\end{array}$ & $\begin{array}{l}\text { ISMT } \\
\text { and } \\
\text { ICS, } \\
\text { vol- } \\
\text { ume }\end{array}$ & $\begin{array}{l}\text { ISMT } \\
\text { and } \\
\text { ICS, } \\
\text { value }\end{array}$ & $\begin{array}{c}\text { ISMT } \\
\text { and } \\
\text { ICS, } \\
\text { vol- } \\
\text { ume }\end{array}$ & $\begin{array}{l}\text { ISMT } \\
\text { and } \\
\text { ICS, } \\
\text { value }\end{array}$ & $\begin{array}{c}\text { ISMT } \\
\text { and ICS, } \\
\text { volume }\end{array}$ & $\begin{array}{l}\text { ISMT } \\
\text { and } \\
\text { ICS, } \\
\text { value }\end{array}$ & $\begin{array}{c}\text { ISMT } \\
\text { and ICS, } \\
\text { volume }\end{array}$ & $\begin{array}{c}\text { ISMT } \\
\text { and } \\
\text { ICS, } \\
\text { value }\end{array}$ \\
\hline 2002 & 15472 & 11667 & - & - & - & - & 100 & 100 & - & - & 0 & 0 \\
\hline 2003 & 22412 & 12831 & 6940 & 1164 & 44,86 & 9,98 & 144,86 & 109,98 & 154,72 & 116,67 & 44,86 & 9,98 \\
\hline 2004 & 30044 & 17409 & 7632 & 4578 & 34,05 & 35,68 & 134,05 & 135,68 & 224,12 & 128,31 & 49,33 & 39,24 \\
\hline 2005 & 51706 & 23222 & 21662 & 5813 & 72,1 & 33,39 & 172,1 & 133,39 & 300,44 & 174,09 & 140,01 & 49,82 \\
\hline 2006 & 94707 & 24101 & 43001 & 879 & 83,16 & 3,79 & 183,16 & 103,79 & 517,06 & 232,22 & 277,93 & 7,53 \\
\hline 2007 & 143454 & 23599 & 48747 & -502 & 51,47 & $-2,08$ & 151,47 & 97,92 & 947,07 & 241,01 & 315,07 & $-4,3$ \\
\hline 2008 & 141853 & 24443 & -1601 & 844 & $-1,12$ & 3,58 & 98,88 & 103,58 & 1434,54 & 235,99 & $-10,35$ & 7,23 \\
\hline 2009 & 147222 & 24178 & 5369 & -265 & 3,78 & $-1,08$ & 103,78 & 98,92 & 1418,53 & 244,43 & 34,7 & $-2,27$ \\
\hline 2010 & 78523 & 29710 & -68699 & 5532 & $-46,66$ & 22,88 & 53,34 & 122,88 & 1472,22 & 241,78 & $-444,02$ & 47,42 \\
\hline 2011 & 192391 & 31464 & 113868 & 1754 & 145,01 & 5,9 & 245,01 & 105,9 & 785,23 & 297,1 & 735,96 & 15,03 \\
\hline 2012 & 170707 & 32352 & -21684 & 888 & $-11,27$ & 2,82 & 88,73 & 102,82 & 1923,91 & 314,64 & $-140,15$ & 7,61 \\
\hline 2013 & 177591 & 35223 & 6884 & 2871 & 4,03 & 8,87 & 104,03 & 108,87 & 1707,07 & 323,52 & 44,49 & 24,61 \\
\hline 2014 & 202588 & 34667 & 24997 & -556 & 14,08 & $-1,58$ & 114,08 & 98,42 & 1775,91 & 352,23 & 161,56 & $-4,77$ \\
\hline 2015 & 231986 & 35190 & 29398 & 523 & 14,51 & 1,51 & 114,51 & 101,51 & 2025,88 & 346,67 & 190,01 & 4,48 \\
\hline 2016 & 590687 & 35307 & 358701 & 117 & 154,62 & 0,33 & 254,62 & 100,33 & 2319,86 & 351,9 & 2318,39 & 1 \\
\hline 2017 & 850582 & 36554 & 259895 & 1247 & 44 & 3,53 & 144 & 103,53 & 5906,87 & 353,07 & 1679,78 & 10,69 \\
\hline 2018 & 834564 & 42942 & -16018 & 6388 & $-1,88$ & 17,48 & 98,12 & 117,48 & 8505,82 & 365,54 & $-103,53$ & 54,75 \\
\hline 2019 & 762063 & 41659 & -72501 & -1283 & $-8,69$ & $-2,99$ & 91,31 & 97,01 & 8345,64 & 429,42 & $-468,59$ & -11 \\
\hline
\end{tabular}

In 2019, compared to 2018, Volume of Payments decreased by 72501 bln. KZT or $8.7 \%$. Number of Payments decreased by 1,283 thousand transactions, or $3 \%$.

The maximum increase in Volume is observed in 2016 (358701 bln.KZT), Number of Payments in 2018 (6388 thousand transactions).
The minimum increase was recorded in 2019 (-72501 bln. KZT), Number of Payments in 2019 (-1283 thousand transactions).

The rate of increase shows that the trend of the series is increasing, which indicates an increase in the Number and Volume of Payments. The following table 3 shows the basic indicators of the series of dynamics. 
Table 3 - Basic indicators of a number of dynamics of ISMT and ICS

\begin{tabular}{|c|c|c|c|c|c|c|c|c|}
\hline \multirow[b]{2}{*}{ Period } & \multirow[b]{2}{*}{$\begin{array}{c}\text { ISMT } \\
\text { and ICS, } \\
\text { volume }\end{array}$} & \multirow[b]{2}{*}{$\begin{array}{l}\text { ISMT and } \\
\text { ICS, value }\end{array}$} & \multicolumn{2}{|c|}{ Absolute increase } & \multicolumn{2}{|c|}{ Growth rate, $\%$} & \multicolumn{2}{|c|}{ The rate of increase, $\%$} \\
\hline & & & $\begin{array}{c}\text { ISMT } \\
\text { and ICS, } \\
\text { volume }\end{array}$ & $\begin{array}{l}\text { ISMT and } \\
\text { ICS, value }\end{array}$ & $\begin{array}{l}\text { ISMT and } \\
\text { ICS, volume }\end{array}$ & $\begin{array}{l}\text { ISMT and } \\
\text { ICS, value }\end{array}$ & $\begin{array}{l}\text { ISMT and } \\
\text { ICS, volume }\end{array}$ & $\begin{array}{l}\text { ISMT and } \\
\text { ICS, value }\end{array}$ \\
\hline 2002 & 15472 & 11667 & - & - & - & - & 100 & 100 \\
\hline 2003 & 22412 & 12831 & 6940 & 1164 & 44,86 & 9,98 & 144,86 & 109,98 \\
\hline 2004 & 30044 & 17409 & 14572 & 5742 & 94,18 & 49,22 & 194,18 & 149,22 \\
\hline 2005 & 51706 & 23222 & 36234 & 11555 & 234,19 & 99,04 & 334,19 & 199,04 \\
\hline 2006 & 94707 & 24101 & 79235 & 12434 & 512,12 & 106,57 & 612,12 & 206,57 \\
\hline 2007 & 143454 & 23599 & 127982 & 11932 & 827,18 & 102,27 & 927,18 & 202,27 \\
\hline 2008 & 141853 & 24443 & 126381 & 12776 & 816,84 & 109,51 & 916,84 & 209,51 \\
\hline 2009 & 147222 & 24178 & 131750 & 12511 & 851,54 & 107,23 & 951,54 & 207,23 \\
\hline 2010 & 78523 & 29710 & 63051 & 18043 & 407,52 & 154,65 & 507,52 & 254,65 \\
\hline 2011 & 192391 & 31464 & 176919 & 19797 & 1143,48 & 169,68 & 1243,48 & 269,68 \\
\hline 2012 & 170707 & 32352 & 155235 & 20685 & 1003,33 & 177,29 & 1103,33 & 277,29 \\
\hline 2013 & 177591 & 35223 & 162119 & 23556 & 1047,82 & 201,9 & 1147,82 & 301,9 \\
\hline 2014 & 202588 & 34667 & 187116 & 23000 & 1209,38 & 197,14 & 1309,38 & 297,14 \\
\hline 2015 & 231986 & 35190 & 216514 & 23523 & 1399,39 & 201,62 & 1499,39 & 301,62 \\
\hline 2016 & 590687 & 35307 & 575215 & 23640 & 3717,78 & 202,62 & 3817,78 & 302,62 \\
\hline 2017 & 850582 & 36554 & 835110 & 24887 & 5397,56 & 213,31 & 5497,56 & 313,31 \\
\hline 2018 & 834564 & 42942 & 819092 & 31275 & 5294,03 & 268,06 & 5394,03 & 368,06 \\
\hline 2019 & 762063 & 41659 & 746591 & 29992 & 4825,43 & 257,07 & 4925,43 & 357,07 \\
\hline N & Created & authors & n sourc & & & & & \\
\hline
\end{tabular}

In 2019, compared to 2002, the Volume of Payments increased by 746591 bln. KZT or by $4825.4 \%$, Number of Payments increased by 29992 thousand transactions or by $257.1 \%$.
The average level of the series $y$ of the dynamics characterizes the typical value of the absolute levels. Table 4 shows the main results of calculations.

Table 4 - Results of the analysis of the series of dynamics of ISMT and ICS (from 2002 to 2019)

\begin{tabular}{|c|c|c|c|}
\hline Indicator & Formula & Volume of Payments & Number of Payments \\
\hline $\begin{array}{l}\text { The average } \\
\text { level of the } \\
\text { interval series }\end{array}$ & $\bar{y}=\frac{\sum y_{i}}{n}$ & $\begin{array}{c}\bar{y}=\frac{4738552}{18}=263252,89 \mathrm{bln} . \\
\text { KZT }\end{array}$ & $\begin{array}{c}\bar{y}=\frac{516518}{18}=28695,44 \\
\text { thousand transactions }\end{array}$ \\
\hline $\begin{array}{l}\text { Average growth } \\
\text { rate }\end{array}$ & $\overline{T_{p}}=\sqrt[n-1]{\frac{y_{n}}{y_{1}}}$ & $\overline{T_{P}}=\sqrt[17]{\frac{762063}{15472}}=1,2576$ & $\overline{T_{P}}=\sqrt[17]{\frac{41615}{11667}}=1,0777$ \\
\hline $\begin{array}{l}\text { Average rate of } \\
\text { increase }\end{array}$ & $\overline{T_{n p}}=\overline{T_{p}}-1$ & $\overline{T_{n p}}=1.2576-1=0,258$ & $\overline{T_{n p}}=1.0777-1=0,078$ \\
\hline $\begin{array}{l}\text { Average } \\
\text { absolute growth }\end{array}$ & $\overline{d y}=\frac{y_{n}-y_{1}}{n-1}$ & $\begin{array}{l}\overline{d y}=\frac{762063-15472}{17}= \\
43917,12 \text { bln. KZT. }\end{array}$ & $\begin{array}{c}\overline{d y}=\frac{41615-11667}{17}=1764,24 \\
\text { thousand transactions }\end{array}$ \\
\hline
\end{tabular}


From 2002 to 2019, Volume of Payments increased annually by $25.8 \%$, Number of Payments by $7.8 \%$. Average absolute growth is a generalized characteristic of individual absolute increases in a number of dynamics.
Let's carry out the forecast for 1 year ahead, using the absolute growth rate for Number of Payments, then Volume of Payments. Compiled by the authors using the Analytical service «Indicators of a number of dynamics online» [22].

$$
\begin{aligned}
& y(19)=762063+43917,12=805980,12 \text { bln. KZT (Volume of Payments). } \\
& y(19)=41659+1764,24=43423,24 \quad \text { thousand transactions (Number of Payments). }
\end{aligned}
$$

The analysis of the series of dynamics shows an increase in the use of online payments in Kazakhstan through the ISMT and ICS systems in the near future.

This trend can be associated with the socioeconomic situation of the population. According to the Statistics Committee of the Ministry of National Economy of the Republic of Kazakhstan, compared to the previous year, GDP in 2020 decreased by $2.6 \%$. The consumer price index in 2020 compared to 2019 increased by $7.5 \%$. The volume of industrial production (goods, services) made up $91 \%$ of last year's indicators. The volume of retail trade in value terms is 11,571.6 million tenge, with an index of $95.9 \%$ in relation to 2019 . The unemployment rate made up $4.9 \%$ of the population in the 4th quarter of 2020 .
In Kazakhstan, the emergency regime was introduced from March 15 to May 11, 2020 by Decree of the President of the Republic of Kazakhstan No. $285(309,310)^{1}$. First of all, the activity of trade and cultural and entertainment facilities was suspended. A restriction was introduced on movement in the territory of the Republic of Kazakhstan. Many enterprises have been switched to remote operation. However, the number of payments (Figure 1) through the ISMT and ICS systems for 2020 increased and amounted to 51,085 thousand transactions compared to the forecasted value of $43,423.24$ thousand transactions.

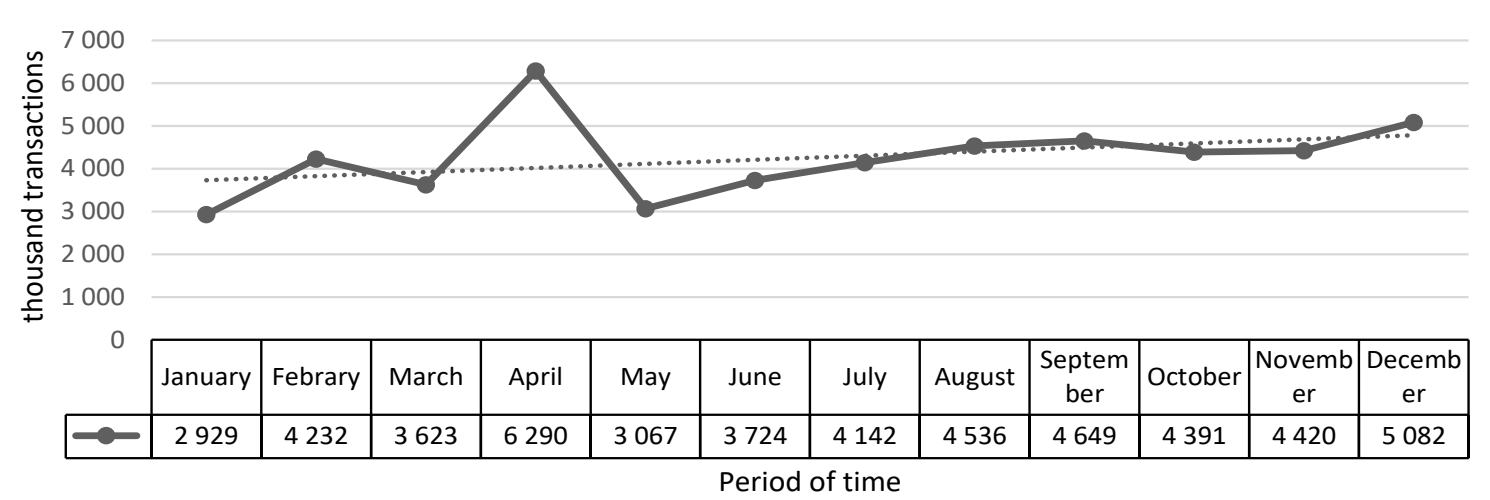

Figure 1 - Number of transactions for 2020 (ISMT \& ICS)

Having carried out a graphical analysis of the number of cashless payments, there can be observed an upward trend. Moreover, in April 2020, the largest number of transfers was carried out (6290). This shows that the lockdown had a positive effect on the dynamics of transfers in Kazakhstan.

If we consider the volume of cashless payments (Figure 2) made through the ISMT and ICS systems, we can see that since the beginning of 2020 the volume of payments has a downtrend.
According to the forecast, the volume of transactions was supposed to make up 805,980.12 bln. KZT, but in 2020645493.444 bln KZT passed through the studied systems (only $80,1 \%$ ).

\footnotetext{
1 Decree «On the introduction of a state of emergency in the Republic of Kazakhstan» of the President of the Republic of Kazakhstan on March 15, 2020 No. 285 (Decree $«$ On the extension of the state of emergency in the Republic of Kazakhstan» dated April 14, 2020 No. 306, the Decree «On the extension of the state of emergency in the Republic of Kazakhstan» dated April 29, 2020 No. 310).
} 


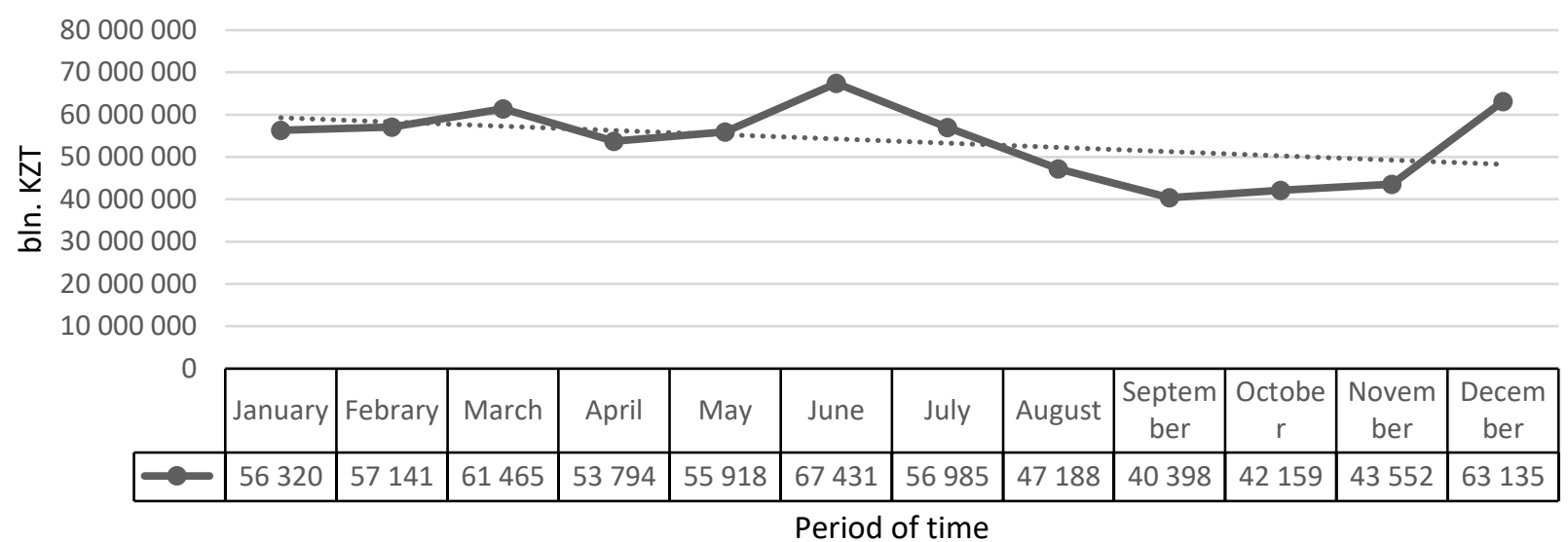

Figure 2 - The volume of transactions for 2020 (ISMT \& ICS)

The studies carried out show deviations from the predicted values. The actual value of Number of Payments in 2020 is 51,085 thousand transactions, the forecast value $(43,423.24)$ is exceeded by $17.6 \%$. Volume of Payments is 645,493.444 bln. KZT from the forecast $(805,980.12)$, which is $19.9 \%$ less.

Thus, the following conclusions can be drawn: hypothesis 0 (the COVID-19 pandemic did not affect the use of cashless payments in Kazakhstan) - is rejected;

hypothesis 1 - (the COVID-19 pandemic influenced the use of cashless payments in Kazakhstan) - has a logical confirmation in this article.

\section{Conclusion}

As a result of the study, statistics were collected on transactions passing through national payment systems. The impact of the COVID-19 pandemic on the transformation of cashless payments in Kazakhstan has been proven.

However, simply writing and implementing programs for payments is not enough, it is necessary to retrain personnel, orient the population towards the transformation of financial technologies, which can lead to an improvement in the socioeconomic development of the country and increase the competitiveness of Kazakhstan in the field of cashless payments. The scope of the research results is the opportunity for other scientists to use the materials of this article to study the impact of the COVID-19 pandemic on the economy of Kazakhstan. Also, the development of national payment systems can reduce the level of fraud in the financial sector, increase the speed of cashless transfers and neutralize transaction errors.

Study limitation: only national payment systems ISMT and ICS were used. In the future, other payment systems registered on the territory of Kazakhstan can be investigated for research.

\section{References}

1. Das S.R. (2019). The future offintech. Financial Management, 48(4), 981-1007. https://doi.org/10.1111/ fima. 12297

2. Fu J., \& Mishra M. (2020). The Global Impact of COVID-19 on Fintech Adoption. Swiss Finance Institute Research Paper, (20-38). https://papers.ssrn. com/sol3/papers.cfm?abstract $\mathrm{id}=3588453$

3. Ren T., \& Tang Y. (2020). Accelerate the Promotion of Mobile Payments during the COVID-19 Epidemic. Innovation (New York, N.y.), 1, 100039 100039. doi: 10.1016/j.xinn.2020.100039

4. Cao T. (2021). The Study of Factors on the Small and Medium Enterprises' Adoption of Mobile Payment: Implications for the COVID-19 Era. Frontiers in Public Health, 9, 122. DOI:10.3389/fpubh.2021.646592

5. De' R., Pandey N., \& Pal A. (2020). Impact of digital surge during Covid-19 pandemic: A viewpoint on research and practice. International Journal of Information Management, 55, 102171 - 102171. doi: 10.1016/j.ijinfomgt.2020.102171

6. Hung A.A., Parker A.M., \& Yoong, J. (2009). Defining and Measuring Financial Literacy. EduRN: Financial Economics Education (FEN) (Topic). http:// dx.doi.org/10.2139/ssrn.1498674

7. Bilal M.A., Khan H.H., Irfan M., Haq S., Ali M., Kakar A., ... \& Rauf A. (2021). Influence of Financial Literacy and Educational Skills on Entrepreneurial Intent: Empirical Evidence from Young Entrepreneurs of Pakistan. The Journal of Asian Finance, Economics, and Business, 8(1), 697-710. https://doi.org/10.13106/ jafeb.2021.vol8.no1.697

8. Niu G., Zhou Y., \& Gan H. (2020). Financial literacy and retirement preparation in China. PacificBasin Finance Journal, 59, 101262. DOI:10.1016/j. pacfin.2020.101262

9. Lee, David Kuo Chuen and Teo, Ernie G. S., Emergence of FinTech and the LASIC Principles (November 7, 2015). Journal of Financial Perspectives, Vol. 3, No. 3, 2015, Available at SSRN: https://ssrn.com/ abstract $=3084048$

10. Chen L. (2016). From Fintech to Finlife: the case of Fintech Development in China. China Economic Journal, 9(3), 225-239. DOI:10.1080/17538963.2016.1 215057

11. GSM Association (2008), "GSMA calls for PayBuy-Mobile handsets", available at: http://gsmworld. 
com/newsroom/press-releases/2008/2090.htm\#nav-6 (accessed January 12, 2010).

12. Kanniainen L. (2010). Alternatives for banks to offer secure mobile payments. International Journal of Bank Marketing, 28(5), 433444. doi:10.1108/02652321011064926

13. Mazer R., \& Rowan P. (2016). Competition in mobile financial services: Lessons from Kenya and Tanzania. The African Journal of Information and Communication, 2016(17), 39-59. https://hdl.handle. net/10520/EJC-7cb8e4224

14. Omarini A. (2018). Fintech and the Future of the Payment Landscape: The Mobile Wallet Ecosystem - A Challenge for Retail Banks? International Journal of Financial Research, 9, 97-116. http://dx.doi. org/10.5430/ijfr.v9n4p97

15. George G., Haas M., \& Pentland A. (2014). Big Data and Management. Academy of Management Journal, 57, 321-326. https://doi.org/10.5465/ amj.2014.4002

16. Clacher I., Doriye J., Mohamed S.R., \& Satta T.A. (2006). Challenges facing banking in emerging markets: A case study of the Tanzanian national payments systems. Journal of Financial Regulation and Compliance, 14, 112-118. https://doi. org/10.1108/13581980610644798
17. Duncan G.T., Gorr W.L., \& Szczypula J. (2001). Forecasting analogous time series. In Principles of forecasting (pp. 195-213). Springer, Boston, MA. DOI: 10.1007 / 978-0-306-47630-3 10

18. Ebert J.F., Huibers L., Christensen B., \& Christensen M.B. (2018). Or web-based questionnaire invitations as a method for data collection: crosssectional comparative study of differences in response rate, completeness of data, and financial cost. Journal of medical Internet research, 20(1), e24. https:// doi:10.2196/jmir.8353

19. National Bank of the Republic of Kazakhstan, [Electronic resource]. URL: https://nationalbank.kz/ru/ news/sistema-mezhbankovskogo-kliringa (access date: 05/10/2020).

20.Avraamov A.I. Statistics: Methodological instructions for the implementation of course work. M.: MADI, 2018.

21. Balinova V.F. Statistics in questions and answers: Textbook allowance. - M.: TK. Welby, Prospect Publishing House, 2004.

22. Analytical service "Indicators of a number of dynamics online" (https://axd.semestr.ru/dinam/chainindices.php (access date: 05/10/2020)).

\section{Information about the authors}

Anna Kredina - corresponding Author, doctoral student ,University of International Business, Kazakhstan, Almaty, Abay Avenue 8a, A25D4T6 (050010), 87012862176, E-mail: anna.kredina@uib.kz, ORCID 0000-0002$7682-2727$

Aigul Akparova - candidate of Economics, PhD, Associate Professor of KKSON MES RK, Professor of University, Kazakhstan University of International Relations and World Languages named Abylai Khan, Kazakhstan, Almaty, Muratbayev street 200, 050022, 8701727 0810, E-mail: aigul.akparova@mail.ru. ORCID 0000-0003-00853057

László Vasa - PhD, Full professor (Faculty of Economics), Széchenyi István University, Győr, Hungary, E-mail: laszlo.vasa@ifat.hu, ORCID 0000-0002-3805-0244

\section{Авторлар туралы мәліметтер}

Кредина Анна Александровна - хат-хабаршы авторы, докторант Халықаралық Бизнес Университеті, Қазақстан, Алматы, Абай даңғылы 8A, A25D4T6 (050010), 87012862176, E-mail: anna.kredina@uib.kz, ORCID 0000-0002-7682-2727

Акпарова Айгуль Аманжоловна - Э. ғ. к., PhD, ҚР БҒМ БҒСБК қауымдастырылған профессоры, Абылай хан атындағы Қазақстан Халықаралық қатынастар және әлем тілдері университеті, Қазақстан, Алматы, Мұратбаев көшесі 200, 050022, 8701 7270810, E-mail: aigul.akparova@mail.ru, ORCID 0000-0003-0085-3057

Васа Ласзло - PhD, Сечени Иштван Университеті, Дьер, Венгрия, E-mail: laszlo.vasa@ifat.hu, ORCID 0000-0002-3805-0244

Дата поступления: 13.05.2021.

Прошла рецензирование: 18.05.2021. Принято решение о публикации: 04.06.2021.

Received: 13.05.2021. Reviewed: 18.05.2021. Accepted: 04.06.2021. 